\title{
Injury Reduction at Fermilab
}

By Bill G riffing

Head, ES\&H Section

J une 2005

\begin{abstract}
Success usually comes to those who a re too busy to be looking for it.
\end{abstract}
-- Henry David Thoreau

In a recent DOE Program Review, Fermilab's director presented results of the laboratory's effort to reduce the injury rate over the last decade. The results, shown in the figure below, reveal a consistent and dramatic downward trend in OSHA recordable injuries at Femilab. The High Energy Physic s Program Office has asked Fermilab to report in detail on how the laboratory has achieved the reduction. In fact, the reduction in the injury rate reflects a change in safety culture at Femilab, which has evolved slowly over this period, due to a series of events, both planned and unplanned. This paper attempts to describe those significant events and analyze how each of them has shaped the safety culture that, in tum, has reduced the rate of injury at Fermilab to its current value.

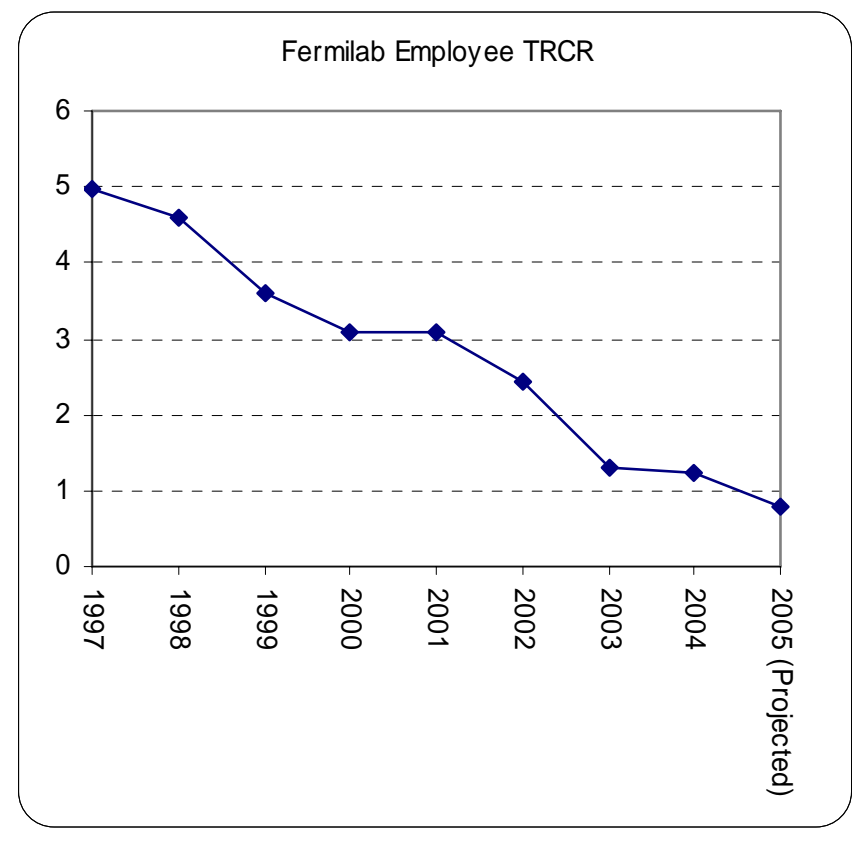

Some would point to the Tiger Team experience of the early 1990's as the initiating event that began to reshape Fermilab's sa fety culture. While it is true that this event was unprecedented in terms of ra ising worker's safety a wa reness at the time, it ca mied with it many negative experiences that tended to somewhat offset its positive influence. For the cynics who thought of safety as a bureaucratic and non-value-added obstacle to science, the Tiger Teamsapproach tended to reinforce that notion. 
For Fermilab, the first real opportunity to improve the safety culture came two years later when, in 1995, Fermilab workers participated in the Necessary and Suffic ient (N\&S) process to identify a "Work Smart" set of safety standards for incorporation into the contract with DOE. The sense of worker empowerment inherent in this process, which we now also recognize as a key principle in Integrated Safety Management (ISM), was something new, energizing and liberating to the Fermilab community. Fermilab's flagship role a mong the DOE labs in embarking on this process and camying it through to successful completion, much like its role in camying out science projects, had the immediate effect of elevating safety to a higher plane of respect and credibility - although not yet equal to the level of science. Certa inly, workers believed that the previous non-value-added safety requirements had been eliminated from the contract and replaced with real stepstoward an approach comparable to that found in private industry.

The liberation that resulted from the a doption of a Work Smart set of sa fety standards in 1995 afforded Fermilab the time, resources, and opportunity to look more closely at intemal processes, services, and systems with an eye toward self-driven improvement. Many innovative changes, too numerous to delve into here, were initiated between 1995 and 1997. They resulted in better ES\&H service, tools, and training. Chief among these innovations was the "tripartite" self-assessment process wherein representatives from the DOE site office, the ES\&H Section, and the line organization partnered to review some mutually-agreed upon aspect of sa fety program implementation. Worker attitude toward safety slowly but surely began shifting in a positive direction. Many additional measures were planned, a waiting time and opportunity for senior management support when Fermilab was overtaken by an unplanned event.

It is often diffic ult to view a serious accident as anything but a negative and unfortunate occurrence. To a safety director, however, it at once becomes an invaluable opportunity to gamer senior management support for initiatives to propel the safety culture forward dramatic ally and quic kly. While no one wishes for accidents, a failure to capita lize on them renders them still more tragic.

For Fermila b, the first major event that served to dra matic ally transform the safety culture was a 1997 arc-blast accident that sent two subcontract electricians to the hospital with serious bums. This event affected Fermilab in two signific ant ways. First, it eventua lly (though not immediately) disabused us of the notion that we did not share responsibility for the sa fety of our subcontractors. The laboratory's fa ilure to properly supenvise and oversee the work of fixed-price subcontract 
workers was undeniable as a contributing factor in this accident. The la boratory la unc hed a series of training courses for construction coordinators and task managers who oversee subcontract workers following this event, designed to improve the understanding of safety requirements and responsibilities. These courses continue to evolve and improve to this day.

Second, the preparation of the corrective action plan in response to this accident created the opportunity for us to propose DuPont safety tra ining for Fermilab management. Until this time, there had been little or no training offered to management in how to manage safety. In achieving support for this relatively expensive tra ining proposition, we were extremely fortunate to have recently added an Associate Director for Operations Support within the Directorate who used his prior experience ga ined elsewhere to persuade others of thinking of this expense as a $n$ investment rather than a cost. The training that followed throughout 1998 in a series of separate classes taught by former DuPont plant managers had an immediate and notic eable impact on the worker injury rates. That investment continues to pay dividends.

Although the timing of this management training could not have been predicted since it was a consequence of the aforementioned arc-blast accident, it fortunately coincided with the roll-out of the laboratory's Integrated Safety Management Plan - a requirement of DOE instituted at that time. The principles of ISM have long been ingrained in the safety culture at DuPont, so it was possible to incorporate ISM training into the DuPont safety course without the necessity for redundant training. Not only did that make the training process more effic ient, but it helped to avoid the inevitable perception that a rises with multiple courses or initiatives - a "flavor of the month." Having a consistent message about sa fety is imperative; having too many different initiatives promotes cynic ism a bout all of them.

In a special session of the DuPont sa fety course held in ea rly 1998, a commitment to reduction in worker injunies was extracted from senior laboratory management. This was signific a nt because it was the first attempt to do so and was not ea sily accomplished. Until taking the course - and even after having taken it - some senior managers still had diffic ulty bringing themselves to believe that they could influence the worker injury rate. Why set injury-reduction goals, they rea soned, if it was beyond their ability to control the outcome? Despite this hesitation, they made a leap of faith; they set and publicly announced safety goa ls. In retrospect, announc ing the injury-reduction goals not just for the coming year, but for each of the successive two years, tumed out to be a wise decision. It 
served notice to the workers that management wascommitted to this objective and recognized that it would require a susta ined, multi-year effort. Quick fixes would not be suffic ient; long-term systemic changes would be necessary.

In addition to the DuPont Sa fety training a s well as other improvements in 1998, the laboratory made three other changes that might appear minor, yet when viewed in hindsight, positively influenced Fermilab's safety culture in a major way. The first of these was to restructure the safety committee and its reporting subcommittees so as to include more worker involvement in polic $y$, in procedure development, and in the resolution of technical safety questions. As in the N\&S standard-setting process, empowered workers took greater ownership of sa fety for themselves a nd for others.

The second change was to begin the distribution of a handout at each weekly senior management meeting listing the injuries reported to the medic al department for the preceding week. Previously it was not uncommon for a division head to be unawa re that a worker in the division had sustained an injury. Without a wa reness, ma nagers applied little pressure down the management chain to conduct a thorough investigation of the cause of the injury or to ensure that it would not recur. This weekly distribution a lmost instantly ac hieved management a wa reness and involvement. Senior mana gers discovered quic kly that they were expected to be able to provide an explanation to the directorfor each injury and what preventive actions had been taken. The elevation of discussion and status of safety performance to the same level of disc ussion and status of accelera tor operations for the first time placed science and safety on the same plane.

The third change was to encourage line managers to begin holding celebrations for sa fety a chievements. Previously, celebrations traditiona lly recognized scientific achievement. Eventually, over time, it became acceptable, even expected, to treat sa fety a chievement on a par with science milestones. Since that time, many safety celebrations have occurred, with special a wards or recognition given to ind ividuals or tea ms for their contributions to safety.

In late1998, a nother unplanned event occurred. Two subc ontractor workers were seriously bumed when they inadvertently ignited a flammable material they were using to strip a floor at Fermilab. This accident taught us yet a nother lesson, which was that it is not enough to work out a hazard assessment (HA) with a subcontractor and then leave the contractor to do the work unsupervised. The facts in this accident 
revealed that in spite of a reasonably good HA, subcontractors may deviate from the work plan and get into trouble. The lessons from this accident, and others, continue to be used in our attempts to teach task managers that it is impossible to be too inquisitive or too trusting in overseeing the work of subcontract workers.

To ca pita lize on this a c cident and a ddress wea knesses in our sa fety system identified by the tripartite assessments, the laboratory called for a stand-down in order to tra in all Femilab and subcontract workers in the process of preparing HA's and in the value of proper work planning.

A number of planned events occurred in 1999 that positively influenced the safety culture. Pushing the reward and recognition theme, the Laboratory Safety Committee created a "Most Improved Safety Performance" annual award to be given to the division or section showing the greatest injury reduction performance in a given year. Eventually, the laboratory created a second a ward to honor the division or section showing the "best susta ined safety performance." Femilab expended much effort during this year in preparing the laboratory for its preverific ation review, and eventually, its verific ation review of ISM implementation by an extemal DOE review team. Likewise, and simulta neously, signific a nt effort went into the construction completion of the Ma in Injector and the commissioning of this new accelerator. But the most signific ant event was the a nnouncement of a new director to lead Fermilab into the 21st century. From the onset, Dr. Witherell a nnounced his intention to camy forward the initia tive to reduce injuries that had been sta rted by Dr. Peoples. A messa ge to all employees during his first week on the job left no doubt that he considered this one of his highest obligations as lab director.

When construction of the NuMI Project began in eamest during 2000, Fermilab management and ES\&H staff were optimistic that the laboratory was well-prepa red for this complex and diffic ult construction project. Changes in the safety culture were apparent to everyone, and we expected that the NuMI Project would set records for safety a chievement. However, we soon began to rea lize that Femila b's improved safety culture clashed with that of the construction contractor from the mining industry. In the three years required to complete this major construction project, Fermilab was able to positively influence the safety culture of this contractor, but not before one major accident (resulting in a Type A investigation), several serious injuries, and the insistence that key contractor personnel be replaced on the project. Ironic ally, this contractor's injury performance improved so dramatically that it was 
a warded a nother large contract in priva te industry in the Pacific Northwest based on the injury record achieved at Fermilab.

Following the construction accident in mid-2001 resulting in the Type A investigation, Fermilab took a dditional measures yet a ga in to strengthen and build on the previous improvements to the construction safety program. Although initial mea sures were taken before his a mival, we were fortunate to have a new Associate Director for Operations Support, with simila r qua lities to those of his predecessor, take over the helm of steering Fermilab through the final sta ges of contractual reform and construction contractormanagement. The new Associate Director also took a more aggressive role in guid ing the activities of the LSC subcommittees, walking the work spaces to talk to workers about safety, and promoting safety a chievement. Under his lea dership, the laboratory achieved signific ant advances in several technic al a reas, partic ula rly electric al sa fety.

In 2002, Fermilab began the distribution of a handout conta ining key ES\&H leading and lagging indic ators at the weekly senior management meeting. Like the injury report, this new report had an immediate effect on the injury rates-especially when the indic ator results were "colorized" in early 2003 to show level of performance by each division and section. This tool provided senior mana gement its first op portunity to tell at a glance where the problems were that directly or ind irectly contributed to Fermilab's overa ll injury rate. Pride in organizational performance undoubtedly led several organizations to seek safety improvements through greater line management involvement and peer pressure.

A new medium for raising safety a wareness became available in 2003 when Fermilab introduced a da ily electronic newsletter with distribution to all workers. Not only was it now possible to communic ate safety information in a timely manner but this medium could be used to share success stories and highlight the sa fety ac hievements of workers, teams, and organizations. Soon after, the ES\&H Section and the Public Affairs office teamed up to produce a weekly "Safety Tip of the Week" column, creating even greater interest and awa reness.

Encouraged by its success and now convinced of its a bility to shape its sa fety future, Fermilab senior mana gement took the bold step of preparing its first Annual ES\&H Plan in 2004. This pla n established a vision for the ES\&H Program, identified goals and captured action plans for the continuous improvement of worker safety a s well a s environmental protection. The laboratory intends to use this plan as the basis for a more vigo rous self-a ssessment plan in 2005. 
As we look back over the joumey we have taken over the last decade, we recognize that the combination of planned and unplanned events have shaped our safety culture into its current form. (See Append ix A.) It is now commonly accepted that Fermilab's safety culture has changed.

The Fermilab community now recognizes that it cannot a chieve excellence in science without excellence in safety. Although many workers in line and support staff organizations have contributed signific a ntly, leadership at the Directorate and Division Head level has had the greatest impact on the behavio ral tra nsformation of workers attitudes and way of thinking about safety. There is little doubt that the success in reducing injuries is directly correlated to the degree of involvement and importance attached to the subject by the highest levels of Fermilab leadership.

\section{Appendix A}

\begin{tabular}{|c|c|}
\hline Timeline & \\
\hline Jul-95 & Work Smart Set approved \\
\hline May-96 & Safety subcommittees need overhaul (most "meet only if nec essary") \\
\hline Jun-96 & Reorga nize the central ES\&H training function \\
\hline Oct-96 & ES\&H Web page launched; paperless FESHM, \& links to ES\&H tools \\
\hline Jan-97 & Beg in Trip artite Assessment Proc ess \\
\hline Apr-97 & First Draft of ISM Prepared \\
\hline Mar-97 & $\begin{array}{l}\text { Reorganize \& revitalize sa fety committee structure; get ES\&H staff working } \\
\text { together }\end{array}$ \\
\hline May-97 & $\begin{array}{l}\text { AUl loses contract at BNL; Pena cites imbalance between science \& sa fety; } \\
\text { Peoples addresses FNAL workforce }\end{array}$ \\
\hline Jun-97 & George Robertson named new Associate Director for Operations Support \\
\hline Jun-97 & Regular disc ussion of injuries \& sa fety performance at Scheduling Meetings \\
\hline Oct-97 & $\begin{array}{l}\text { Arc Blast Acc ident; Contra c tor \& Elec tric al safety a ddressed; impetus for DuPont } \\
\text { Tra ining supported by Direc to rate }\end{array}$ \\
\hline Feb-98 & $\begin{array}{l}\text { Began DuPont Training with Sr. Mgmt; First disc ussion of setting goals (for next } \\
\text { three years!). }\end{array}$ \\
\hline Feb-98 & With Robertson's lea dership, begin more formal training of task managers \\
\hline Mar-98 & Annual ESHEC format requires each D/S Head to make presentation \\
\hline Mar-98 & Dr. Peoples a ddresses LSC; LSC minutes reflect pride taken in safety records \\
\hline Mar-98 & Beg in Conducting DuPont Training for Managers \& Supervisors/ISM Princ iples \\
\hline Apr-98 & Begin disc ussing each injury at weekly Sc heduling Meeting \\
\hline May-98 & First round of safety celebrations using URA money \\
\hline Oct-98 & Medical Department transferred from LSS to ES\&HS \\
\hline Oct-98 & Kitchen Fire Accident; Emphasis on HA's \& Work Pla nning \\
\hline Dec-98 & Lab Stand-down to train everyone $\&$ subcontractors on HA's \\
\hline
\end{tabular}




\begin{tabular}{|c|c|}
\hline Jan-99 & Dr. Foxen hired; better case management \\
\hline Feb-99 & $\begin{array}{l}\text { Femi News story about progress in meeting lab-wide goals to reduce DART rate; } \\
\text { goals for next two years }\end{array}$ \\
\hline Mar-99 & LSC Awards to D/S for Most Improved Sa fety Performance \\
\hline Apr-99 & Pre-Verific a tion of ISM by DOE \\
\hline Jul-99 & Main Injector commissioned \\
\hline Jul-99 & J ohn Peoples/Mike Witherell Tra nsition \\
\hline Sep-99 & Verification of ISM by DOE \\
\hline Feb-00 & $\begin{array}{l}\text { Femi News story about progress in meeting lab-wide goals to reduce DART rate; } \\
\text { goal for next year }\end{array}$ \\
\hline May-00 & NuMI Construction Prep work begins \\
\hline Aug-00 & New LSC format emphasizing regular periodic reports by subcommittees \\
\hline 2001 & NuMI Construction Starts in eamest \\
\hline Jun-01 & $\begin{array}{l}\text { Dilling rig accident; even grea ter emphasis on construction sa fety oversight; } \\
\text { many changes }\end{array}$ \\
\hline Jan-02 & Jed Brown named new Associate Director for Operations Support \\
\hline Sep-02 & Introduce leading/lagging indicators \\
\hline Nov-02 & Electric al Safety Subcommittee begins deliberations on NFPA 70E \\
\hline Feb-03 & Introduce color-coded leading/lagging indic ator performance charts \\
\hline May-03 & $\begin{array}{l}\text { First organization (PPD) to go over a million hours without a DARTcase } \\
\text { (celebration) }\end{array}$ \\
\hline Jul-03 & Introduce polo shirt awards w/ completed pic ture. \\
\hline Jul-03 & Fermi To day la unc hed; provides forum for regular communic a tion on safety \\
\hline Aug-03 & Lab surpasses one year without injury case involving days a way from work (a first) \\
\hline Dec-03 & Lab completes first major shutd own w/out injuries; attributed to good planning \\
\hline Feb-04 & Safety Tip of the Week launched in Fermi Today \\
\hline Feb-05 & $\begin{array}{l}\text { First Annual Sa fety Pla n published; conta ins vision for ES\&H Program \& lays out } \\
\text { pla ns for improvement }\end{array}$ \\
\hline
\end{tabular}

